\title{
ZÁVAZNÁ STANOVISKA JAKO FORMA SPRÁVNÍ ČINNOSTI
}

\author{
VÁCLAV PETRMICHL
}

\begin{abstract}
Binding Opinions as a Form of Administrative Activity
The article deals with the concept of binding opinions as a form of administrative activity. The author describes basic principles of binding opinions in the context of curent Czech legislation and the applicability of the principle of binding opinions in decision-making administrative process.
\end{abstract}

Keywords: administrative activity; binding opinions

Klíčová slova: správní činnost; závazná stanoviska

DOI: $10.14712 / 23366478.2020 .11$

Koordinace rozhodovací činnosti v individuálně-rozhodovacích procesech ve veřejné správě je v českém právním prostředí tradičně ztvárněna dvěma základními doktrinálními př́istupy, mezi něž nauka řadí princip řetězení správních aktů a princip subsumpce správních aktů formou závazných stanovisek. Koncept závazných stanovisek, zakotvený v ust. § 149 zák. č. 500/2004 Sb., správní řád, ve znění pozdějších předpisů (dále jen „Spగ̌ “) a označený jako „rozhodnutí správních orgánů, podmíněná závaznými stanovisky“, byl s účinností tohoto zákona od 1. 1. 2006 recipován do české obecné procesní úpravy. Cílem př́spěvku je teoretická reflexe institutu závazných stanovisek jako jedné z forem správní činnosti v českém právním řádu. Př́spěvek se $\mathrm{v}$ širších souvislostech správního práva zaměřuje na základní východiska fungování této formy koordinace rozhodovací činnosti a využitelnost konceptu závazných stanovisek v různých typech správního rozhodování.

\section{VYDÁVÁNÍ ZÁVAZNÝCH STANOVISEK JAKO FORMA SPRÁVNÍ ČINNOSTI}

Rozhodnutí podmíněná závaznými stanovisky jsou správními akty, které jsou výsledkem projevu vůle dvou či více vykonavatelů veřejné správy, vystupujících v procesních rolích samostatných vzájemně kooperujících orgánů. Závazná stanoviska jsou pak z hlediska teoretické kategorizace nesamostatně existující závazné správní akty, adresované rozhodujícímu správnímu orgánu ${ }^{1}$ jakožto dílčí podkladové úkony,

1 V tomto pojetí byla závazná stanoviska pojímána již starši českou judikaturou. Srov. rozsudek Nejvyššího správního soudu (dále jen „NSS“) ze dne 18. 5. 2005, čj. 2 As 24/2004-138, jakož i rozsudek NSS ze dne 14. 2. 2008, čj. 5 As 77/2006-255. 
spoluutvářející obsah výsledného (finálního) správního rozhodnutí. Závazné stanovisko i konečné správní rozhodnutí jsou akty právně-mocenské povahy, vydávané při výkonu vrchnostenské veřejné správy. Z hlediska strukturálních vztahů jde o projev horizontální koordinace $\mathrm{v}$ individuálně-rozhodovacích procesech ve veřejné správě, původcem i adresátem závazného stanoviska jsou orgány veřejné správy v horizontálním administrativním vztahu, přičemž se nejedná o interní rozhodovací proceduru, ale o normativní vztah mezi dvěma či více vykonavateli vrchnostenské veřejné správy, upravený obecně závaznými právními normami. Lze tak $\mathrm{v}$ tomto smyslu hovořit o koncentraci správních aktů, úhrnných správních aktech, či koordinovaných správních aktech. Z obsahového hlediska je závazné stanovisko prípravným podkladovým úkonem vykonavatele veřejné správy, sloužící jako nástroj pro hodnocení dílčích odborných aspektů předmětu posouzení, atribut závaznosti vede k zezávaznění veřejnoprávních požadavků k předmětu řízení, vznesených a formulovaných odborně způsobilým dotčeným orgánem. Jakkoli jde v prŕpadě závazných stanovisek z procedurálního hlediska formálně vzato o akty se samostatnou právní existencí, signifikantní je naopak jejich nesamostatná povaha navenek, účinky těchto závazných podkladových aktů se promítají navenek vůči adresátům regulatorního působení zprostředkovaně, prostřednictvím výsledného správního rozhodnutí. Absence právotvorných účinků čili chybějící externí závaznost, která je jedním z pojmových znaků správních aktů, sice může vyvolat pochybnost o označení těchto úkonů jako správních aktů, nejde však o contradictio in adiecto. Důvod, proč lze závazná stanoviska označit za nesamostatné správní akty, tkví právě v jednotě závazného stanoviska a konečného rozhodnutí, z hlediska definice správního aktu se tak podmiňující akt a finální akt doplňují a tvoří nedílný celek². Závazné stanovisko je tak akcesorickým institutem, který bez konečného správního rozhodnutí neobstojí, pravomoc vydávat závazná stanoviska lze v tomto ohledu proto považovat za akcesorickou formu správní činnosti.

Koncept závazných podkladových aktů není v českém právu novým př́stupem ke koordinaci rozhodovací činnosti, z pohledu historického vývoje má tento koncept nejen v tuzemské nauce, ale i z pohledu pozitivního práva, nezpochybnitelnou tradici. Z historické perspektivy lze zmínit předně dílo J. Hoetzela, ${ }^{3}$ v němž lze nalézt jednak

2 STAŠA J. In: HENDRYCH, D. a kol. Správní právo. Obecná část. 9. vyd. Praha: C. H. Beck, 2016, s. 162-163. „Sám o sobě podmiňujici akt totiž všechny znaky správního aktu nesplňuje (nemá minimálně vnějsí působnost). Finálni akt je zase naproti tomu projevem vůle více správnich orgánů-nikoli tedy, obsahove vzato, pouze projevem vůle toho správniho orgánu, kterýje jeho bezprostředním pưvodcem."

3 HOETZEL, J. Československé správní právo: část všeobecná. 2. vyd. Praha: Melantrich, 1937, s. 104: „(...) určitý podnik (dillo, zařizení) nebo činnost možno právnicky dostati pod střechu jen tak, že se vydá řada samostatných, oddělených správnich aktů různých úr̆adủ. Každýz těchto úr̆adů je povolán chrániti různé veřejné zájmy, resp. posuzovati tutéž věc s hlediska ri̊zných právních norem. Nemůže tedy napr̆. stavebni úrad samosprávný rešiti si prejudiciálně otázku, lze-li stavěti v zakázaném požárním rayonu

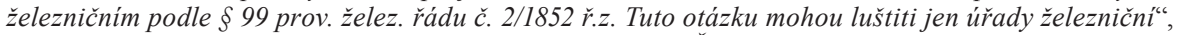
prričemž dále „Sem patř́ např. také 39 venk. stav. ř́ádu pro Čechy č. 5/1889 č.z.z., podle něhož stavební úrad nesmi dáti dř́ve povolení ke stavbě, která je zároveñ živnostenskou provozovnou, než provozovna je schválena úŕadem politickým a stavebni úrad je při tom striktnè vázán podmínkami politického úradu, za kterých tento úr̆ad schválil živnostenskou provozovnu.“ Na str. 105 dále: „Stejně je tomu podle zák. č. 117/1884 r.z. stran opatření k neškodnému sváděni horských bystřin, kde jediné ministerstvo zemédělství rozhoduje o, veřejné užitečnosti' generálního projektu (\$10), takže zemský úr̆ad (\$14) nesmèl by vydati rozhodnutí v 10 předvídané beze predběžného aktu ministerstva zemédělstvi" a dále: 
rozpracování principu řetězení správních aktů, ale i zájem o problematiku subsumpce, judikatura prvorepublikového Nejvyššího správního soudu v některých př́ípadech hovořila o úhrnných aktech více úrudå ${ }^{4}$ rozhraničení mezi řetězením a závaznými podkladovými akty bylo akcentováno i v jiných pramenech. ${ }^{5}$ Tehdejší nauka hovořila o ,zodbornění úřadu“ ${ }^{6} \mathrm{v}$ prrípadě závazných podkladových aktů šlo o to, že správní úr̆ad mohl ve vymezených př́padech vydávat rozhodnutí jen $v$ souhlase s úr̆ady jinými, jen tyto úrady dohromady byly kompetentní k úřednímu aktu, přičemž chyběl-li některý z nich, pak se jednalo o nekompetentně vydaný akt. Teorie referovala o problematice nejen z pohledu organizačních a procedurálních aspektů, ale princip koordinovaného rozhodování rovněž kladla do souvztažnosti se subjektivním právem dotčené osoby na řádné projednání kompetentními úřady v plné šíři, autoři dovozovali nárok stran (dnešním nazíráním účastníků řízení) na to, aby v rozhodnutí samém bylo uvedeno, že rozhodnutí se vydává v souhlase $\mathrm{s}$ určitým úřadem. ${ }^{7}$ Problematika závazných podkladových aktů a závazné formy koordinace se netýkala jen prvostupňového rozhodování, řada předpisů zakotvovala povinnost opatřit závazné podkladové akty i pro účely rozhodování o opravných prostředcích, ${ }^{8}$ činil tak kupř. zákon o vyvlastnění za účelem výstavby železnic, ${ }^{9}$ či některé další předpisy. ${ }^{10}$ Problematiku koordinovaných rozhodnutí v kontextu instančního

„Rovněž zemský úřad by nesměl schvalovati zařizení elektrického podniku dřive, než tento podnik je prohlášen za všeužitečný (zák. o soustavné elektrisaci č. 438/1919 Sb.).“

4 Viz kupř. nález Boh. 8065/29. Judikaturu k úhrnným aktům shrnuje v komentáři k ust. § 2 zák. o NSS, na str. 80 publikace HÁCHA, E. - RÁDL, Z. Nejvyšši správní soud: normy o jeho zřizení a působnosti, komentované podle judikatury býv. správního soudního dvora a nejvyššího správního soudu s použitím materialii a písemnictví. Praha: Československý kompas, 1933.

5 K. Laštovka v pojednání o zvláštních částech „správního e práva, konkrétně v oblasti stavební úpravy, zmiňuje následující: „V některých připadech nestači $k$ stavbě povolení stavebního úřadu, nýbrž jest třeba vedle tohoto povolení i povolení nebo souhlasu úr̆adu jiného; při tom někdy stavebni úr̆ad nesmí uděliti stavebni povolení, dokud si neopatřil povolení tohoto jiného úr̆adu, a jest obsahem tohoto povolení vázan, jindy stavebni úrad udili sice povolení, ale stavebnik nesmi se stavbou započiti, dokud si sám neopatřil povoleni jiného orgánu. “LAŠTOVKA, K. Československé správní právo. Část zvláštní. I. díl. Praha: MELANTRICH, 1936, s. 112-113.

6 Dle J. Hoetzela se k zodbornění úřadu nepůsobí jen přímým složením úřadu rozhodujícího, ale i prostřednictvím „,normy o tom, že jeden úřad má jednati se souhlasem nebo aspoň po slyšení úřadu jiného“. HOETZEL, c. d., s. 340.

7 KLIMENT, J. - ZEIS, E. Československé správní řizení. Sv. 36. Praha: V. Linhart, 1937. V rámci výkladu o věcné příslušnosti k ust. $§ 5$ zák. č. 8/1928 Sb., s. 45.

8 Zjevně ovšem nešlo o pravidlo, zdaleka ne všechny předpisy takový mechanismus zakotvovaly, čehož si všímá i J. Hoetzel v díle HÁCHA, E. - HOBZA, A. - HOETZEL, J. - WEYR, F. - LAŠTOVKA, K. Slovník veřejného práva československého. Svazek I. Brno: Polygrafia-Rudolf M. Rohrer, 1929, na str. 45 konstatováním, že: „o stížnosti rozhodují v dohodě úřady, které jsou oněm stolicím nadřizeny. To neni nic samožrejmého, ale právní řád mívá podobná výslovná ustanovení (...).“

9 Dle $\$ 18$ zák. č. 30/1878 ř.z., jenž se týče vyvlastňování k účelu stavění železnic a provozování jízdy po nich, o rekursu proti vyvlastňovacímu nálezu přísluší rozhodovati ministerstvu vnitra po dohodě s ministerstvem obchodu a s jinými ministerstvy správními, jichž působností se dotýkají otázky, které se mají rozhodnouti.

10 Dle $\S 13$ odst. 1 zák. č. 55/1928 Sb., o cestovních pasech platilo, že: „O prostředcích opravných proti rozhodnutím politických úřadi̊ platí všeobecné předpisy. Rozhoduje-li zastupitelský úr̆ad (\$ 4, odst. 1), možno podati stížnost u tohoto úr̆adu do 15 dnů k ministerstvu vnitra, které o ní rozhodne v dohoděs ministerstvem zahraničních věcí. Pro počitáni této lhůty platí všeobecná ustanovení o odvolacích lhůtách v řizení správním“, či v případě rozhodování ministerstva zemědělství dle ust. § 24 zák. č. 297/1921 Sb., o povinném známkování chmele. 
postupu rovněž reflektovala i dobová teorie, ${ }^{11}$ která s odkazem na tehdejší judikaturu dovozovala, že opravný prostředek proti koordinovanému rozhodnutí je nutno podat k úřadu, který příslušné rozhodnutí vydal, a to dle procesních pravidel platných pro úřad tohoto druhu, přičemž jemu instančně nadřízený úřad byl povinen rozhodovat $v$ dohodě $\mathrm{s}$ úruadem instančně nadřízeným tomu, který rozhodoval v dohodě v prvním stupni. ${ }^{12}$ Takový postup byl možný však pouze tehdy, pokud měly dotčené úřady své instančně nadřízené úřady, v opačném př́ipadě byl daný dílčí výrok výrokem konečným. ${ }^{13} \mathrm{Jde}-$ -li o genezi institutu závazných stanovisek v pozitivním právu, je namístě zmínit, že obecná procesní úprava koncept závazných podkladových aktů až do účinnosti správního řádu z roku 2004 neupravovala, závazné formy koordinace rozhodovací činnosti tak byly v rakouském a později i v československém veřejném právu toliko záležitostí zvláštních úprav, z nejstarších pramenů lze zmínit předně předpisy z oblasti horního práva, ${ }^{14} \mathrm{z}$ oblasti živnostenského podnikání, ${ }^{15}$ shodně lze dokladovat různé formy koordinace i v poválečném období, kupř́ikladu v oblasti vodního práva, ${ }^{16} \mathrm{v}$ oblasti stavebního práva, ${ }^{17}$ či v řadě dalších zvláštních předpisů.

\section{ZÁVAZNÁ STANOVISKA V PLATNÉ PRÁVNÍ ÚPRAVĚ}

Koncept správních rozhodnutí se subsumovanými závaznými podkladovými akty představuje jedno z možných řešení problematiky komplexního rozhodování $\mathrm{s}$ přesahem do působnosti více správních úřadů. V české právní úpravě došlo $\mathrm{k}$ zakotvení závazných stanovisek na úrovni obecného procesního předpisu až přijetím zákona

11 Obsáhlejší zmínku lze nalézt kupř. v díle KLIMENT - ZEIS, c. d., s. 232-233 (kapitola o instančním pořadu při úhrnných aktech).

12 Z nálezu Boh. A. 333/20 lze vyčíst (cit.): „Stižnost podána budiž u úr̆adu, jenž nález v dohodě s druhým úradem vydal, podle zásad platných pro řizení instanční pred úrady jeho druhu. Rozhodnutí o stižnosti musí se státi v dohodě obou úř́adů nadrízených, tak jako se stalo rozhodnutí vodpor brané.“

13 Viz nález Boh. A. 7848/29: „Otázku, zda výrok vydaný součinně dvěma organisačně různými úřady (...) podléhá rádnému opravnému prostředku čili nic, sluši posuzovati podle toho, je-li pro orgány takto $k$ součinnosti povolané resp. pro každý z nich o sobě ustanoven orgán nadřizený, at již společný, at' různý; jestliže bud' žádný neb aspoň jeden z obou úradů není postaven pod stolici vyšší, dlužno výrok onen pokládati za konečný.“

14 Srov. císařský patent č. 146/1854 ř.z. obecný horní zákon (ve znění předpisů jej měnících a doplňujících ke dni 1. 1. 1930).

15 Dle 1143 císařského patentu č. 227/1859 ř.z., jímž se vydává a od 1. května 1860 počínajíc v působnost uvádí řád živnostenský pro celý rozsah říše (kromě správního obvodu benátského a Vojenské hranice) (živnostenský řád) šlo o rozhodování Ministeria obchodu jakožto nejvyšší stolice ve věcech živnostenských $\mathrm{v}$ dohodě s jiným ústředním úradem, týkala-li se projednávaná věc i působnosti tohoto ústředního správního úřadu.

16 Zák. č. 11/1955 Sb., o vodním hospodářství, upravoval nejen různé konzultativní formy participace, řetězení správních aktů, ale i závazné podkladové akty, dle $\$ 37$ zákona byly vodohospodářské orgány pro vydání rozhodnutí povinny opatřit závazný posudek orgánů hygienické a protiepidemické služby. Obdobně též dle $\S 8$ odst. 1 písm. e) zák. č. 138/1973 Sb., o vodách (vodní zákon), vodohospodářský orgán vydával vodoprávní povolení k odběru či užívání důlních vod, které důlní organizace nepotřebují $\mathrm{k}$ vlastnímu provozu, $\mathrm{v}$ dohodě s př́ílušným báňským úřadem, dalším př́íladem bylo rozhodování o uložení nápravných opatření dle $\S 16$ odst. 2 zákona $\mathrm{v}$ dohodě s př́ílušnými orgány.

17 Dle $\S 23$ zák. č. 87/1958 Sb., o stavebním řádu, šlo o rozhodování o př́ípustnosti stavby na území důležitých pro obranu státu jen v dohodě s vojenskou správou či byl vyžadován její předchozí souhlas ke stavebním úpravám. 
č. 500/2004 Sb., správní řád, s účinností od 1. 1. 2006. Definice závazného stanoviska je obsažena v ust. § 149 odst. 1 věta první SpŘ, dle něhož je závazné stanovisko „úkon učiněný správním orgánem na základè zákona, který není samostatným rozhodnutím ve správním ř́zení a jehož obsah je závazný pro výrokovou část rozhodnutí správniho orgánu“. Mezi definiční znaky závazného stanoviska tak patří: 1. zákonný základ, 2. atribut závaznosti pro výrokovou část správního rozhodnutí, 3. povaha závazného stanoviska jakožto úkonu učiněného správním orgánem, který není samostatným rozhodnutím (negativní znak).

Dotčené veřejné zájmy (životní prostředí, ochrana kulturního dědictví, požární bezpečnost apod.) nejsou v rozhodovacích procesech chráněny generálně, 18 nýbrž pouze $\mathrm{v}$ rámci konkretizovaných zákonných zmocnění $\mathrm{k}$ vydání závazných stanovisek, existence a rozsah zákonných zmocnění $\mathrm{k}$ vydávání závazných stanovisek by měly vycházet z potřeby hmotného práva chránit jednotlivé veřejné zájmy. Jednotlivá zmocnění k vydání závazných stanovisek vždy však musejí mít v souladu se zásadou legality ( 2 odst. $1 \mathrm{SpR}$ ) a s ohledem na ústavní východiska pro výkon státní moci ${ }^{19}$ normativní základ. Závazné stanovisko tak nelze vydat praeter legem, požadavek na zákonný podklad je současně i výhradou zákona vylučující možnost zakotvit pravomoc k vydání závazného stanoviska podzákonným právním předpisem či dokonce interním normativním aktem. Koncept subsumpce je toliko platformou pro spolurozhodování více orgánů, a jako jedna $\mathrm{z}$ forem koordinace rozhodovací činnosti nikterak nevypovídá o úrovni ochrany jednotlivých veřejných zájmů, jejíž konkrétní obsah je výlučně záležitostí jednotlivých zvláštních předpisů. Konkrétní zákonný podklad k vydání závazného stanoviska není určující jen pro existenci zmocnění, ale i pro jeho obsah, konkrétně pak pro rozsah, meze a hlediska posouzení, těžiště využití závazných stanovisek spočívá v rozhodovacích agendách, v nichž nelze dílčí výstupy automatizovat, a kde se uplatňuje naopak diskreční pravomoc dotčených orgánů, a to jak pokud jde o celkový výsledek posouzení, tak i pokud jde o modifikaci závazných stanovisek formou podmínek (modus).

Stěžejním znakem závazných stanovisek je pak jejich závaznost pro obsah správního rozhodnutí. Závazné stanovisko představuje privilegovanou formu odborného stanoviska, které spoluutváří obsah konečného správního rozhodnutí, je určují pro posouzení dílčích aspektů projednávané věci, vylučuje v tomto směru uplatnění diskrečního oprávnění správního orgánu, jemuž je závazné stanovisko adresováno. Judikatura hovoří v této souvislosti o hmotněprávním aspektu závazných stanovisek. ${ }^{20}$ Závaznost je vlastnost závazného stanoviska jako celku, ve správním rrízení předcházejícímu vydání konečného rozhodnutí je nutno respektovat jak výsledek posouzení, tedy zda jde o ne-

18 Zákonné zmocnění k vydání závazného stanoviska nezakládá sama o sobě ani vymezená věcná působnost v určité rozhodovací agendě, kupř. dle rozsudku KS v Ostravě ze dne 6. 9. 2016, čj. 22 A 161/2014-34, nelze bez výslovného zákonného zmocnění dovodit pravomoc př́slušného OBÚ k vydání závazného stanoviska pro povolení stavby, zahrnující vrty, vykazující znaky činnosti prováděné hornickým způsobem ve smyslu § 3 písm. f) zák. č. 61/1988 Sb., o hornické činnosti, výbušninách a o státní báňské správě.

19 Čl. 2 odst. 3 Ústavy ĆR, čl. 2 odst. 2 Listiny základních práv a svobod.

20 Dle rozsudku NSS ze dne 30. 1. 2009, čj. 2 As 41/2008-77: „Závazné stanovisko podle § 149 správního rádu tedy má jak aspekt hmotněprávní (předurčuje obsah meritorního správniho rozhodnutí), tak aspekt procesni (vyžádáni závazného stanoviska od dotčeného správního orgánu je nezbytnou podmínkou pro vydání rozhodnutí ve věci samé a nedodrženi této podmínky zakládá nezákonnost naposledy zmínéného rozhodnutí).“ 
souhlasné (negativní) či souhlasné (pozitivní) závazné stanovisko, tak i všechna jeho vedlejší ustanovení. Platí, že negativní závazné stanovisko předurčuje celkový výsledek řízení a obsah koordinovaného rozhodnutí, negativní podmiňující akt znamená, že negativní bude i výsledný finální akt, ${ }^{21}$ tato kauzalita je positivně vyjádřena v ust. § 149 odst. $4 \mathrm{Sp} \check{R}^{22}$. Obsah závazného stanoviska tak nelze z pohledu rozhodujícího správního orgánu jednostranně překlenout, $v$ př́padě kolize obsahu závazného stanoviska s budoucím obsahem správního rozhodnutí či s obsahem jiného závazného stanoviska zákon předvídá proceduru formalizovaného řešení rozporu. ${ }^{23}$

Zvláštní úprava bud' explicitně zakotvuje pravomoc vydat závazné stanovisko, či zakládá pravomoc vydat akt, který materiálně odpovídá znakům závazného stanoviska. ${ }^{24,25}$ Materiální př́stup k posouzení právní povahy těchto aktů plyne přímo z ust. $§ 149$ odst. 1 SpŘ , dle něhož je závazné stanovisko definováno jednotlivými znaky, aniž by přistupoval formální znak. Toto východisko však není poplatné pouze recentní úpravě v ust. § $149 \mathrm{SpŘK}$, materiální př́stup k posouzení povahy těchto aktů je pro funkčnost subsumpce klíčovým prvkem, opačný (formální) přístup by vyvolával obtiže v tom, že by určitá skupina úkonů, byt' principiálně totožné povahy, výslovně neoznačená jako závazná stanoviska, zůstala nedůvodně deregulována a vyňata $\mathrm{z}$ režimu fungování závazných stanovisek. Závaznou povahu aktu lze pak z legislativně-technického hlediska vymezit různým způsobem, terminologie je co do označení závazných stanovisek různorodá, ve zvláštních předpisech jde o značně heterogenní skupinu různě pojmenovaných úkonů, řada označení vychází z historické setrvačnosti a vyskytuje se shodně ve více generacích zvláštních předpisů. Tato nejednotná a roztř́ššěná terminologie, symptomatická pro zvláštní části správního práva, zjevně ani zde nesvědčí

21 STAŠA, J. Problém subsumpce správních aktů. AUC Iuridica, 2002, č. 1-2, s. 87-98.

22 Jde o konkretizaci pravidla v $\$ 51$ odst. 3 SpŘ. Byt' § 149 odst. 4 SpŘ hovoří o závazném stanovisku vydaném v průběhu řízení, předmětné pravidlo pochopitelně cílí na př́ípady negativních závazných stanovisek, lhostejno zda opatřených v průběhu řízení, či před jeho zahájením.

23 Ust. § 136 odst. 6 SpŘ. Srov. blíže PETRMICHL, V. Koordinovaná správní rozhodnutí a řešení rozporu. Správní právo, 2019, roč. LII, č. 7, s. 347-367.

24 Z materiálního pojetí závazných stanovisek vychází i judikatura. Srov. rozsudek NSS ze dne 29. 11. 2012, čj. 4 As 52/2012-26: „Pokud zvláštní zákon výslovně neurčuje, že podle něj vydávaná stanoviska jsou závazným stanoviskem ve smyslu správního r̆ádu z roku 2004, ani neuvádí, že se jedná o správní rozhodnutí, je rozhodujicí, zda př́slušné stanovisko podle zvláštního zákona naplňuje znaky závazného stanoviska vymezené v 149 správního rádu z roku 2004 a konkretizované v judikatuře správních soudư", rozsudek NSS ze dne 30. 1. 2009, čj. 2 As 41/2008-77, v případě charakteru souhlasu s umistováním staveb a zařízení v chráněném ložiskovém území (CHLÚ), či rozsudek Krajského soudu (dále jen „KS“) v Praze ze dne 18. 5. 2016, čj. 48 A 35/2014-63, ve vztahu k povaze vodoprávního souhlasu dle § 17 zák. č. 254/2001 Sb., o vodách a o změně některých zákonů (vodní zákon), pro účely rozhodovacích procesů dle stavebního zákona.

25 Záhy po účinnosti správního řádu z roku 2004 materiální povahu závazných stanovisek dovodil poradní sbor ministra vnitra ke správnímu řádu v závěru č. 11 ze dne 12. 9. 2005 (posouzení povahy souhlasu Ministerstva zdravotnictví (dále jen „MZ“) k činnostem v ochranných pásmech a na území lázeňského místa), přičemž následně přijal obecný závěr o materiálním posouzení povahy závazného stanoviska, pod č. 31 ze dne 10. 4. 2006: „Závazná stanoviska či souhlasy podle zvláštních zákonů (podminuujicí úkony) je třeba posuzovat jednotlivě podle jejich povahy vycházejicí ze zvláštních zákonü. Ustanovení § 149 správního ř́du předpokládá, že zvláśtni zákon stanoví formu, jakou bude př́slušný podmiňujicí úkon učiněn. Tyto podmiñujici úkony jsou závaznými stanovisky podle § 149 správního rádu, pokud odpovídaji znakům vymezeným v 149 odst. 1 správniho řádu. V prípadě, že ze zvláštního zákona vyplývá, že podmiňujici úkon má charakter rozhodnutí, nemůže se jednat o závazné stanovisko podle § 149 správního ř́du." 
právní jistotě, řadu rozhodovacích forem a vazeb mezi akty je nutno určovat v souladu s materiálním pojetím závazných stanovisek na základě logických či systematických argumentů, hraniční se mnohdy nejeví jen posouzení závazné povahy aktu, ale i to, zda rozhodovací forma vykazuje znaky závazného stanoviska či samostatného rozhodnutí. Z hlediska vyjádření v právním předpise se jednoznačným jeví především explicitní (přímé) označení aktu jakožto závazného stanoviska nebo samostatně či současně s odkazem na ust. $\S 149$ SpŘ přímo v textu ustanovení, popř. v poznámce pod čarou ${ }^{26}$, či ve společných ustanoveních daného předpisu, na enumerativní výčet ve společných ustanoveních se mnohdy ovšem s ohledem na zmíněné materiální pojetí závazných stanovisek nelze při výkladu vždy zcela spolehnout. Prvek závaznosti může být přímo inkorporován $\mathrm{v}$ jazykovém prostředku, 27 či je vázanost stanoviskem vyjádřena samostatnou výslovnou zmínkou o závaznosti aktu, ${ }^{28}$ či určením, jak s daným aktem procesně nakládat, kupř. formou nemožnosti odchýlit se od jeho obsahu. ${ }^{29} \mathrm{~V}$ právním rádu lze nalézt pojmy jako závazný posudek, závazné vyjádření, souhlas, schválení, povoleni či jiné alternativy. Některé zvláštní úpravy důsledně terminologicky odlišují závazné podkladové akty určené pro obsah správního rozhodnutí a výlučně ty označují za závazná stanoviska, ${ }^{30}$ některé zvláštní předpisy pojem závazného stanoviska naopak užívají largu sensu k souhrnnému označení závazných podkladových aktů pro vícero forem správní činnosti, ${ }^{31}$ terminologie je však ošidná, některé úkony, dle jiných předpisů verbis expressis označené jako závazná stanoviska, však ve skutečnosti závaznými stanovisky ve smyslu ust. $§ 149$ SpŘ nejsou. ${ }^{32}$ Zmocnění k vydání závazného stanoviska může vyplývat i z předepsaného zpơsobu participace, v legislativní praxi se vyskytují různá označení, závaznou formu aktu implikuje forma rozhodování ,v dohodě“ 33 či ,,po dohoděc, kterou lze dokladovat typicky v oblasti stavebního práva, ${ }^{34}$ jakož i v environ-

26 Srov. pozn. pod čarou 2a) § 11 odst. 3 zák. č. 20/1987 Sb., o státní památkové péči (dále jen „PamZ“). Poznámky pod čarou však nemají normativní, ale jen interpretační význam.

27 Závazný posudek orgánu veterinární správy dle § 56 zák. č. 166/1999 Sb., o veterinární péči a o změně některých souvisejících zákonů (veterinární zákon) (dále jen „VetZ“), vydávaný jako podklad ve stavebním ř́zení, ze shodného principu i terminologie vycházela též předchozí úprava v § 24 odst. 2 zák. č. 87/1987 Sb., o veterinární péči.

28 Kupř. vyjádření orgánu ochrany prrírody k projektům pokusů na volně žijících zvířatech, jehož závazná povaha plyne z výslovného znění § 23a odst. 3 zák. č. 246/1992 Sb., na ochranu zvířat proti týrání (dále jen „TyrZvZ“), kde je vymezeno, že „(...) vyjádření je pro státní orgán př́slušný ke schvalování projektı̊ pokusư závazné".

29 Ust. § 56 odst. 2 VetZ: „Orgán přislušný rozhodnout ve věci podle zvláštnich právních předpisů nemůže rozhodnout v rozporu s timto posudkem.“

30 Srov. § 31 odst. 4 zák. č. 133/1985 Sb., o požární ochraně.

31 Srov. terminologii v $\S 5$ odst. 4 zák. č. 324/2016 Sb., o biocidech, dle něhož je pojem závazné stanovisko Ministerstva životního prostř̌edí (dále jen „MŽP“) a Ministerstva zemědělství (dále jen „MZe“) užíván promisque pro účely různých postupů $\mathrm{MZ}$ dle ust. $\$ 5$ odst. 2 písm. a)-i) zákona, některé z těchto postupů zjevně nevykazují znaky individuálně-rozhodovací činnosti.

32 Např. jde-li o závazná stanoviska komor dle § 2 odst. 2 písm. i) zák. č. 220/1991 Sb., o České lékařské komoře, České stomatologické komoře a České lékárnické komoře, týkající se odborných problémů poskytování zdravotních služeb a zdravotnického výzkumu, či kupř. záväzné stanovisko Finančného riaditelstva $\mathrm{k}$ užití daňových předpisů dle § 53a zák. č. 563/2009 Z.z. o správe daní (daňový poriadok) a o zmene o doplnení niektorých zákonov.

33 Dle rozsudku NSS ze dne 17. 12. 2007, čj. 1 As 32/2005-162, spojení „,v dohode“ představuje požadavek na vyjádření shodné společné vůle.

34 Dle § 176 odst. 1 zák. č. 183/2006 Sb., o územním plánování a stavebním řádu (stavební zákon) (dále jen „StZ“) v př́ípadě, že při výstavbě dojde k nepředvídaným nálezům kulturně cenných předmětů, 
mentálních předpisech. ${ }^{35}$ Dohoda je výsledkem společné vůle (shody) zúčastněných správních orgánů, vyznačující se volnější formou projevu vůle, ${ }^{36}$ vlastní rozhodování pak může zákon svěřit teoreticky bud' jednomu správnímu orgánu v potřebné koordinaci s jiným dotčeným orgánem, či může jít o rozhodování obou orgánů v dohodě, aniž by zákon předurčoval rozdělení procesních rolí. ${ }^{37}$ Ani v jednom př́ípadě se však nejedná o konsensuální projev navenek, jde toliko o nástroj koordinace při tvorbě společné úřední vůle. ${ }^{38}$ Dohoda musí být z podstaty věci učiněna před vydáním rozhodnutí ve věci (ex ante), dohoda vylučuje i následné formalizované dohodovací řízení dle ust. $§ 136$ SpŘ. Obdobný význam lze přisuzovat i rozhodování „se souhlasem“, 39 přičemž souhlasem je vyjádřena jednak závazná forma stanoviska, ale i skutečnost, že jde o úkon předcházející výslednému posouzení. Naopak v př́ípadě forem koordinace, označených jako „po projednáni" ${ }^{40}$, „po vyjádřeni“, „,v součinnosti“ či „,ve spolupráci“ se jedná

detailů stavby nebo chráněných částí přírody anebo $\mathrm{k}$ archeologickým nálezům, rozhodne stavební úřad „v dohoděs príslušným dotčeným orgánem stanoví podminky $k$ zabezpečení zájmů státní památkové péče a ochrany prírody a krajiny“. Dalším příkladem je povolování výjimek z obecných požadavků na výstavbu dle ust. § 169 odst. $6 \mathrm{StZ}$, rozhodnutí o výjimce „lze vydat jen v dohodě nebo se souhlasem dotčeného orgánu, který háji zájmy chráněné podle zvláštnich právních předpisư, kterých se odchylné řešení týká،.

35 Srov. rozhodování stavebního úřadu o nařízení nezbytných úprav dle $§ 33$ odst. 5 zák. č. 44/1988 Sb., o ochraně a využití nerostného bohatství (horní zákon), ve znění pozdějších předpisů (dále jen „HorZ“) „v dohodě s obvodním báňským úřadem vlastníku dotčených staveb (...)“, či dále § 65 zák. č. 114/1992 Sb., o ochraně př́ŕrody a krajiny (dále jen „PřKrZ“): „Orgán státní správy vydávajicí rozhodnutí podle zvláśtnich předpisửi2), jimiž mohou být dotčeny zájmy chráněné tímto zákonem, tak činí jen po dohodě s orgánem ochrany prírody, neni-li v zákonè predepsán jiný postup.“

$36 \mathrm{~K}$ rozvolněnosti formy mnohdy inklinuje i odborná literatura. Komentářová literatura v kontextu zmíněné úpravy PřKrZ připouští i protokol z místního šetření, z něhož bude zřejmá shoda. Srov. STEJSKAL, V. Zákon o ochraně př́rody a krajiny. Komentár. Praha: Wolters Kluwer ČR, 2016, s. 350.

37 Takovým (spíše ojedinělým) příkladem je rozhodování ústředních správních úřadů v dohodě dle $§ 169$ odst. 1 písm. c) SpǨ, pokud jde o řešení sporů z některých veřejnoprávních smluv ve sporném rrízení.

38 Z. Červený ŕadí konsensuální projev, kdy „správní orgán může vydat správní akt po dohodě (v dohodě) s jiným orgánem“, který je předpokladem (náležitostí) vydání správního aktu, mezi správní dohody v širším smyslu, přičemž k problematice uvádí: „Předmětem dohody je zde vydáni správního aktu, který však vydá ten z účastníkủ dohody, který je k tomu zmocněn právní normou. Nejde proto o společný správni akt. Přitom práva a povinnosti zakládá (ruši, měni) správni akt, nikoli dohoda. Ta je jen zvláśtni podmínkou tvorby správního aktu a její prípadný nedostatek činí správní akt vadným." ČERVENÝ, Z. In: LUKEŠ, Z. a kol. Československé správní právo. Obecná ćást. Praha: Panorama, 1981, s. 174. B. Voženílek shodně uvádí, že: „Jak normativni, tak individuálni správni akty vydávají správní orgány v řadě prípadů $v$ dohodě (po dohodě) s jinými správnimi orgány. Také v těchto př́ipadech nejde o správni dohody, nýbrž o jednostranné akty. Dohoda mezi orgánem, který akt vydává, a orgány, v dohodè, s nimiž jej vydává, neni samostatnou formou správní ćinnosti, ale prvkem v procesu tvorby aktu." VOŽENÍLEK, B. O správních dohodách. Správní právo, 1979, roč. XII., č. 4, s. 193-204.

39 Ust. $\S 6$ odst. 4 zák. č. 274/2001 Sb., o vodovodech a kanalizacích pro veřejnou potřebu a o změně některých zákonů (zákon o vodovodech a kanalizacích) upravuje v některých př́ípadech předchozí souhlas MŽP k povolení Krajského úřadu (dále jen „KÚ“) k provozování vodovodu nebo kanalizace. Závazným stanoviskem je dle rozsudku NSS ze dne 23. 9. 2014, čj. 1 As 176/2012-140 i souhlas obecného stavebního úřadu dle $\S 15$ odst. $2 \mathrm{StZ}$ pro účely rozhodování speciálních stavebních úřadů.

40 Viz rozsudek NSS ze dne 26. 6. 2013, čj. 4 As 33/2013-28: „Ustanoveni § 24 odst. 2 zákona č. 44/1988 Sb., o ochraně a využití nerostného bohatství, o tom, že predběžný souhlas se stanovením dobývacího prostoru vydává Ministerstvo životního prostředí po projednání s Ministerstvem průmyslu a obchodu stanoví Ministerstvu životního prostředí povinnost žádost konzultovat s Ministerstvem průmyslu a obchodu. Toto ustanovení nebrání tomu, aby Ministerstvo životního prostředí navzdory pozitivnímu stanovisku Ministerstva průmyslu a obchodu (které není závazným stanoviskem ve smyslu § 149 správního rádu z roku 2004) žádost o predběžný souhlas zamitlo, pokud své rozhodnutí řádně odůvodní (...).“ 
o konzultativní formu participace, zahrnující povinnost daný podklad opatřit, jež je někdy poněkud nepatřičně označována jako ,procesní závaznost ${ }^{\prime 4}{ }^{41}$ Ve zvláštní části správního práva lze nalézt nepřeberné množství různých podob závazných stanovisek, ale i řadu atypických institutů, jejichž povaha je mnohdy hraniční. Sporné může být, zda jde o závazná stanoviska (se všemi důsledky z toho plynoucími), ukládá-li zákonná formulace příslušnému správnímu orgánu z podkladového stanoviska ,vycházet“ či ho ,zohlednit" nebo k němu ,přihlédnout“, 42 z povinnosti přihlédnout ke stanovisku judikatura dovozuje závaznost. ${ }^{43}$ Jde o hraniční konstrukce, nacházející se na pomezí mezi závaznými stanovisky a nezávaznými vyjádřeními, striktní vázanost patrně automaticky dovodit nelze, úprava naskýtá určitý prostor pro uplatnění odchylné vůle, což je u závazných stanovisek pojmově vyloučeno. Výše uvedené nasvědčuje, že nejednotná terminologie ke škodě věci znepřehledňuje orientaci nejen veřejné správě, ale z pohledu adresátů práva nepřispívá ani právní jistotě, žádoucím se proto jeví terminologické rozdíly postupně odstranit a v souladu se zásadou jednotnosti právního řádu výlučně pracovat s označením, ,závazné stanovisko“.

Dalším určujícím prvkem pro kategorizaci aktu jakožto závazného stanoviska je negativní znak, totiž že daný akt nevykazuje znaky samostatného správního rozhodnutí ve smyslu ust. $§ 67$ Sp ̌̌. ${ }^{44}$ Základní myšlenka subsumpce stojí na principu, že projevy vůle dotčených orgánů čili závazná stanoviska představují dílčí úkony, jejichž obsah je promítnut navenek prostřednictvím konečného správního rozhodnutí. Obecně proto platí, že zakotvená forma závazného stanoviska musí být vždy komplementární s koncepcí následného povolovacího procesu, a závazné stanovisko musí najít svůj odraz v určeném správním rozhodnutí. Tento imanentní prvek fungování závazných stanovisek se však záhy po účinnosti správního řádu z roku 2004 ukázal jako jeden z neuralgických bodů konceptu subsumovaných správních aktů. To je do značné míry dáno tím, že instrumentárium správního práva $\mathrm{z}$ řady více či méně legitimních důvodů pracuje s různými povolovacími režimy, některé zvláštní úpravy tu a tam nevyžadují k uskutečnění záměru koordinované rozhodnutí vždy, ale variantně v návaznosti na povahu či rozsah záměru či činnosti, někdy umožňují jeho provedení bud' bez další součinnosti správního orgánu, ${ }^{45}$ či na základě aktu jiné právní formy aktu nežli rozhodnutí. Tyto problémy přetrvávají i dnes, v prostředí zvláštních úprav navíc v souvislosti

41 B. Voženílek k povaze těchto forem projednání uvádí: „V řadě dalšich prípadů jsou sice vyjádření apod. také obligatorní, jejich právní význam však nedosahuje takového stupně jako u predchozích (závazných stanovisek, pozn. autora) rozhodujici orgán si je sice musí opatřit (vyžádat), hodnoti je však jako každý jiný podklad rozhodnuti (...).“ VOŽENÍLEK, B. Posudky, vyjádření a stanoviska ve státní správě. Správní právo, 1978, roč. XI, č. 4, s. 197-209.

42 Dle $\S 57$ odst. 1 zák. č. 326/1999 Sb., o pobytu cizinců na území České republiky a o změně některých zákonů, ,při udělováni dlouhodobého viza přihlédne“ MV ke stanovisku příslušného zastupitelského úřadu.

43 Např. rozsudek MS v Praze ze dne 7. 6. 2016, čj. 3A 61/2014-28.

44 Původní návrh správního řádu (sn. tisk č. 201/0, IV. vol. období PSP ČR) definoval negativní prvek víceméně totožně jakožto úkon „u něhož zvláštni zákon nevyžaduje, aby byl vydán jako samostatný správní $a k t^{\prime \prime}$.

45 Záměry či činnosti uskutečnitelné bez interakce vykonavatele veřejné správy (podléhající tzv. volnému režimu) tak musí být v režimu zvláštního předpisu posouzeny formou samostatného správního rozhodnutí. 
se subsumpcí vzniká i řada nových problémů. ${ }^{46}$ Zjevně však nejde jen o otázky vazeb mezi závazným stanoviskem a správním rozhodnutím, koncept závazných stanovisek v současnosti zjevně přesahuje problematiku koordinovaného správního rozhodování v režimu 2. a 3. části SpŘ. Potřeba na legislativní úrovni definovat vztah závazných stanovisek vyvstává i ve vztahu k jiným formám správní činnosti, které jsou koncipovány jako rovnocenná náhrada rozhodnutí podmíněných závazným stanoviskem, jde především o alternativní povolovací formy, obzvláště pak ve stavebním právu (souhlasy, subordinační koordinované veřejnoprávní smlouvy, ale i některé specifické procesní konstrukce jako regulační plán nahrazující koordinované rozhodnutí či certifikát autorizovaného inspektora). Minimálně u některých zmíněných forem by princip subsumpce zasloužil reflexi v obecné právní úpravě ve správním řádu. Lze zmínit především problematiku veřejnoprávních smluv nahrazujících rozhodnutí podmíněná závazným stanoviskem, která nabývá $\mathrm{v}$ kontextu koordinovaného rozhodování $\mathrm{v}$ řadě aspektů zcela nový rozměr, a která by si proto zasloužila podrobněji rozpracovat. Legislativní praxe přinesla ale i jiná řešení, z teoretického hlediska se naopak nepatřičnou jeví konstrukce subsumpce závazného stanoviska do jiného závazného stanoviska (fenomén multiplikace závazných stanovisek), ${ }^{47}$ jde o nevhodný př́stup, vytvářející řadu nepředvídatelných důsledků a s tím spojených závažných výkladových problémů.

\section{TYPOLOGIE SPRÁVNÍHO ROZHODOVÁNÍ S UPLATNĚNÍM ZÁVAZNÝCH STANOVISEK}

Z hlediska typologie správních řízení přichází subsumpce správních aktů do úvahy v podstatě ve všech druzích správního rozhodování, jde předně o povolovací akty (tradičním teoretickým nazíráním členěné na souhlasy a schválení, povolení, koncese), které představují významný podíl koordinovaných rozhodnutí v českém právním řádu. Jde rovněž i o různá rozhodnutí o udělení výjimek z veřejnoprávních povinností, ${ }^{48}$ schvalování odchylných postupů apod. Subsumpce se vyskytuje i u specifických správních aktů regulujících území, př́íkladem může být rozhodování o schválení lesního hospodářského plánu (LHP) na základě závazného stanoviska orgánu ochrany prŕrody 49 či rozhodování o pozemkových úpravách z podnětu pozemkového úřadu. ${ }^{50}$ Využitelnost

46 V oblasti posuzování vlivů na životní prostředí se problematiky jeví především několikanásobná subsumpce téhož závazného stanoviska EIA v rámci několika navazujících rozhodnutí.

47 Viz kupř. § 94j odst. $2 \mathrm{StZ}$ a úprava povolování souboru staveb formou společného územního a stavebního řízení, zakotvená novelou stavebního zákona č. 225/2017 Sb.

48 Dle $\S 54$ odst. 1 zák. č. 111/2006 Sb., o pomoci v hmotné nouzi, mohou krajské pobočky Úřadu práce vydat rozhodnutí o prominutí povinnosti vrátit neoprávněně vyplacenou dávku nad 10000 Kč pouze s předchozím souhlasem Ministerstva práce a sociálních věci (dále jen „MPSV“), či shodně dle $\S 22$ odst. 5 zák. č. 108/2006 Sb., o sociálních službách, lze vydat rozhodnutí krajské pobočky Úřadu práce o prominutí povinnosti vrátit přeplatek př́spěvku na péči v částce nad 20000 Kč s předchozím souhlasem MPSV. Dalším př́íladem je výjimka ze zákazu umistovat stavby a zařízení nesouvisející s dobýváním v chráněném ložiskovém území formou závazného stanoviska KÚ dle § 19 odst. 1 HorZ.

49 Ust. § 4 odst. 3 PřKrZ.

50 Ust. § 3 odst. 3 zák. č. 139/2002 Sb., o pozemkových úpravách a pozemkových úřadech a o změně zákona č. 229/1991 Sb., o úpravě vlastnických vztahů k půdě a jinému zemědělskému majetku. Blíže 
subsumpce lze najít i ve správním rozhodování ve statusových otázkách. ${ }^{51} \mathrm{~V}$ platné úpravě lze dokladovat princip koordinace formou závazných stanovisek i v prŕpadech autorizace osob k vybraným činnostem, ${ }^{52}$ jakož i pokud jde o autorizační rozhodnutí o delegaci části působnosti v oblasti veřejné správy. ${ }^{53}$ Uplatnění závazných stanovisek lze dokladovat ale i v řízeních zahajovaných z moci úřední, relativně samostatnou skupinou je pak kategorie sankčních řízení, která zahrnuje především podskupinu řízení o vydání opatření netrestní povahy, jejichž pojmovým znakem je nápravný, zajištovací a ochranný charakter. Lze zmínit různé druhy rozhodování o uložení preventivních opatření ${ }^{54}$ či nápravných opatření, ${ }^{55}$ poukázat lze i na zvláštní pravomoci stavebního úřadu, ${ }^{56}$ odbornost dotčeného orgánu nalezla uplatnění i v př́ípadě rozhodování o propuštění specifického druhu zboží na trh. ${ }^{57}$ Prvek koordinace v řízeních ex officio je vyžadován jednak z důvodu zajištění ochrany více veřejných zájmů současně, ale mnohdy i k vyřešení jejich vzájemné kolize, preventivní zákaz či omezení činnosti k ochraně jednoho veřejného zájmu mohou zároveň implikovat ohrožení či zásah do jiného veřejného zájmu. Př́íkladem takové sdílené rozhodovací pravomoci je současná úprava kácení dřevin rostoucích mimo les za účelem zajištění provozuschopnosti a bezpečnosti drážního provozu a řešení střetu zájmu na ochraně př́rody, resp. zájmu na zachování dřevin rostoucích mimo les v kolizi s veřejným zájmem na zajištění bezpečnosti a ply-

KNOTEK, J. K formě úkonů dotčených orgánů v řízení o pozemkových úpravách. Časopis pro právní védu a praxi, 2007, roč. 15, č. 2, s. 138-143.

51 Dle $\S 34$ a odst. 3 zák. č. 585/2004 Sb., o branné povinnosti a jejím zajištování (branný zákon), jde o rozhodování $\mathrm{MO}$ o stanovení nebo úpravě vojenské hodnosti občana na základě závazného stanoviska Ústavu pro studium totalitních režimů a Archivu bezpečnostních složek.

52 Rozhodnutí o autorizaci dle § 11 zák. č. 22/1997 Sb., o technických požadavcích na výrobky a o změně a doplnění některých zákonů, ve zvláštních případech podmíněné závazným stanoviskem Státního úřadu pro jadernou bezpečnost (dále jen „SÚJB“") dle $\$ 58$ odst. 3 zák. č. 263/2016 Sb., atomový zákon, či závazným stanoviskem MZ dle $\S 8$ písm. a) zák. č. 268/2014 Sb., o zdravotnických prostředcích a o změně zákona č. 634/2004 Sb., o správních poplatcích.

53 Dle § 5la odst. 2 zák. č. 49/1997 Sb., o civilním letectví, může Ministerstvo dopravy rozhodnutím vydaným se souhlasem Ministerstva obrany pověrit vedením databáze geografických, topografických a geodetických údajů o terénu a překážkách na území ČR právnickou osobu soukromého práva.

54 Způsob zajištění fyzické ochrany jaderného zařízení a jaderného materiálu formou rozhodnutí SÚJB z moci úřední dle § 160 odst. 3 zák. č. 263/2016 Sb., atomový zákon, na základě závazných stanovisek Ministerstva vnitra, Ministerstva obrany a Ministerstva průmyslu a obchodu (dále jen „MPO“). Srov. dále rozhodování o ukládání opatření k vyhubení škodlivých organismů dle § 32 odst. 9 zák. č. 289/1995 Sb., o lesích a o změně a doplnění některých zákonů (lesní zákon), které lze vydat v př́ípadech $\S 31$ PřKrZ pouze souhlasem a v rozsahu stanoveném orgánem ochrany př́rody. K souhlasu orgánu ochrany př́rody dle § 31 PřKrZ srov. též rozsudek NSS ze dne 4. 4. 2013, čj. 3 As 51/2012-124.

55 Rozhodování stavebního úřadu $\mathrm{v}$ dohodě $\mathrm{s}$ orgánem státní památkové péče a orgánem ochrany př́rody dle § $176 \mathrm{StZ}$ o stanovení podmínek pro provádění stavebních prací na základě zjištěných př́ŕrodně či kulturně cenných nálezů.

56 Řízení o nařízení nezbytných úprav dle ust. § 137 StZ ve vazbě na § 11 odst. 3 PamZ, dle něhož lze vydat rozhodnutí, jimiž mohou být dotčeny zájmy státní památkové péče, pouze na základě závazného stanoviska orgánu státní památkové péče, což bylo do 31. 12. 2006 ekvivalentně vyjádřeno jako rozhodování „v dohode“.

57 Srov. závazné stanovisko Ústředního kontrolního a zkušebního ústavu zemědělského (ÚKZUZ) dle § 73a odst. 2 a 3 zák. č. 326/2004 Sb., o rostlinolékařské péči a o změně některých souvisejících zákonů, k propuštění př́ípravku nebo pomocných prostředků na ochranu rostlin pro účely rozhodování celního úřadu. 
nulosti drážního provozu. ${ }^{58}$ Specifickým případem nápravných opatření je i odnímání veřejnoprávních oprávnění, která byla udělena rozhodnutím dle ust. § 149 SpŘ. Zatímco rozhodnutí o přiznání oprávnění je výsledkem správního řízení o žádosti, odnímání oprávnění je z podstaty věci realizováno formou správního řízení ex officio zpravidla náležejícího správnímu orgánu, který vydal výsledné rozhodnutí o přiznání oprávnění. Dotčenému orgánu je pak zpravidla svěřena toliko iniciace zahájení takového řizení, v němž je následně oprávněn vydat negativní závazné stanovisko. ${ }^{59}$ Princip subsumpce správních aktů našel svůj odraz i v oblasti správního trestání, konkrétně jde o specifickou úpravu projednání přestupku na úseku ochrany zvířat proti týrání, ${ }^{60}$ zakotvující závazné stanovisko, označené jako odborné vyjádření krajské veterinární správy (KVS). ${ }^{61}$ Zde však lze pochybovat o vhodnosti přijatého řešení, má-li jít o natolik odborně komplikované otázky, vyžadující ze zákona součinnost odborně způsobilého vykonavatele státní správy (KVS), je otázkou, jakou přidanou hodnotu má lokalizace rozhodování v rámci přeneseného výkonu státní správy u obce s rozšířenou působností, a zda je vskutku konstrukce rozhodnutí o přestupku se subsumovaným závazným stanoviskem (v principu jde o čistou subsumpci par excellence) optimálním řešením a zdali nelze přenést v plném rozsahu působnost na orgány veterinární správy. Stávající procesní instrumentarium správního řádu, zahrnující předně znalecký posudek ( $\$ 56 \mathrm{SpR}$ ) se jeví jako dostatečné, nota bene preferuje-li úprava ve správním řádu ( $\$ 56 \mathrm{SpŘR}$ ) odborné posouzení přímo od odborně způsobilého správního orgánu. V oblasti správního trestání vykazuje prvky koordinace (byt’ nejde o závazná stanoviska) i procesní úprava

58 Kácení dřevin rostoucích mimo les v tomto případě podléhá oznamovacímu režimu dle $\S 8$ odst. 2 PřKrZ. Orgán ochrany prŕírody je oprávněn rozhodnutím oznamované kácení dřevin pozastavit, omezit či zakázat, avšak pouze v případě, že obdrží kladné závazné stanovisko drážního správního úřadu.

59 Př́ikladem takové konstrukce je § 63 odst. 4 ZamZ: „Generální reditelství Úr̆adu práce na základě podnětu Ministerstva vnitra zaháji řizeni o odnětí povoleni ke zprostředkováni zaméstnání právnické osobě nebo fyzické osobě. V tomto řzeni Ministerstvo vnitra vydá nové stanovisko podle § 60a. Generální ředitelstvi Úřadu práce na základě nesouhlasného stanoviska Ministerstva vnitra povolení ke zprostředkováni zaměstnáni právnické osobě nebo fyzické osobě rozhodnutím odejme." Obdržený podnět sice bezprostředně nezahajuje řízení, na základě podaného podnětu je však vyloučena diskrece Generálního ředitelství Úřadu práce stran vyhodnocení předpokladů pro zahájení řízení a zahájení správního řizení je obligatorním postupem.

60 § 24a odst. 5 TyrZvZ: „Obecni úřad obce s rozšiřenou působností si vyžádá v řizení o přestupku odborné vyjádřeni krajské veterinárni správy, které je pro toto řizení závazné. Je-li řizení zahájeno z podnětu krajské veterinárni správy a součástí podnětu je i odborné vyjádření, dalši odborné vyjádření se nevyžaduje. Odborné vyjádřeni se rovněž nevyžaduje v řizeni o přestupku spočivajícím v porušení povinnosti učinit opatřeni proti úniku zvírete."

61 Dle rozsudku NSS ze dne 14. 10. 2010, čj. 7 As 46/2010-54, „[o]dborné vyjádření orgánu veterinární správy vydané podle $\$ 24 a$ odst. 5 zákona č. 246/1992 Sb., na ochranu zvírat proti týrání, naplňuje definiční znaky závazného stanoviska ve smyslu § 149 odst. 1 správního řádu z roku 2004“. K závazné povaze tohoto aktu shodně rozsudek MS v Praze ze dne 29. 1. 2015, čj. 7 A 19/2011-84-90. Dle rozsudku KS v Hradci Králové ze dne 16. 8. 2011, čj. 51 A 21/2010-49, „[o] tom, zda byl spáchán přestupek týrání zviŕrat ve smyslu § 4 odst. 1 zákona č. 246/1992 Sb., na ochranu zvírat proti týrání, rozhoduje př́slušný správni orgán v prestupkovém řizeni, nikoli orgán veterinární správy. Ten totiž v takovýchto př́padech pouze vydává závazné stanovisko ve smyslu § 149 správního ř́du z roku 2004, které není samostatným rozhodnutím ve správním řizení. Účelem závazného stanoviska je toliko podat odborné závěry $k$ projednávané věci, v daném prípadě to, zda se jednalo o týrání zviŕrat, či nikoliv. Právní hodnocení přstupkové věci do něj však nepatři, a proto obsahuje-li je, jako by nebylo." 
některých přestupků v gesci RRTV. ${ }^{62}$ Prvky koordinace za účelem vyhodnocení objektu posouzení ojediněle vykazuje i deklaratorní rozhodování o odstranění pochybností ${ }^{63}$ jak pokud jde o konzultativní koordinaci, ${ }^{64}$ tak i pokud jde závaznou formu posouzení. ${ }^{65}$

Výše učiněný exkurz do zvláštní části správního práva spolehlivě dokládá uplatnění principu subsumpce napříč v podstatě všemi typy správního rozhodování. V tomto ohledu v podstatě nelze shledat žádný limit uplatnění principu subsumpce, jde-li o typovou povahu správního řízení, snad jen vyjma oblasti správního trestání, široká uplatnitelnost subsumpce správních aktů svědčí o univerzalitě této formy koordinace. Lze proto oprávněně konstatovat, že koncept závazných stanovisek pro svůj průr̆ezový charakter patří bezesporu do obecné procesní úpravy.

\author{
Mgr. Václav Petrmichl \\ Právnická fakulta Univerzity Karlovy \\ petrmicv@prf.cuni.cz
}

62 Dle $\$ 13$ odst. 2 zák. č. 132/2010 Sb., o audiovizuálních mediálních službách na vyžádání a o změně některých zákonů, a dle $\S 61$ odst. 2 zák. č. 231/2001 Sb., o provozování rozhlasového a televizního vysílání a o změně dalších zákonů, Rada pro rozhlasové a televizní vysílání v rámci přestupkového řízení „přihliži ke stanovisku věcně príslušného samoregulačniho orgánu uvedeného v seznamu samoregulačnich orgánů, obdrži-li toto stanovisko písemnè do 10 pracovnich dnů ode dne zahájení řizeni".

63 Bliže PETRMICHL, V. Rozhodování v pochybnostech v oblasti práva životního prostředí. Jurisprudence, 2018, č. 2, s. 3-13.

64 Úprava posuzování těžebního odpadu, které je výsledkem rozhodnutí Českého báňského úřradu (dále jen „ČBÚ“"), vydaného po projednání s dotčeným ústředním orgánem státní správy dle § 2 odst. 1 zák. č. 157/2009 Sb., o nakládání s těžebním odpadem a o změně některých zákonů, či rozhodování ČBú o tom, zda jde o výbušninu dle § 21 zák. č. 61/1988 Sb., o hornické činnosti, výbušninách a o státní báňské správě, na základě vyjádření Ministerstva vnitra, Ministerstva obrany a Českého úřadu pro zkoušení zbraní a střeliva, či rozhodnutí MŽP o tom, zda je určitý typ výrobku obalem dle $\$ 32$ písm. m) zák. č. 477/2001 Sb., o obalech a o změně některých zákonů (zákon o obalech), vydané po projednání s MZe.

65 Srov. úpravu v § 3 HorZ, pokud jde o rozhodování MPO o tom, zda je nerost nerostem vyhrazeným či nevyhrazeným, v dohodě s MŽP, či § 35 odst. 7 HorZ o rozhodování MŽP o existenci starých důlních děl v dohodě s MMR a MPO. Nebo ust. §3 odst. 6 zák. č. 505/1990 Sb., o metrologii, kdy v pochybnostech při určování měřidel sloužících pro měření ionizujícího záření a radioaktivních látek rozhoduje Úřad pro technickou normalizaci, metrologii a státní zkušebnictví v dohodě se SÚJB. 